\title{
MICHEL BEHEIM'S \\ VON DEN TÜRKEN UND DEM ADEL SAGT DIS: \\ A DEMOTIC LAMENT AND CRUSADING SONG CONTEMPORARY WITH THE FALL OF CONSTANTINOPLE IN 1453
}

\author{
WILLIAM C. MCDONALD \\ Department of German and Jewish Studies, \\ University of Virginia, Charlottesville, Virginia, 22904, USA \\ e-mail:wcm@virginia.edu
}

Michel Beheim, a prominent 15th-century German author and musical composer - who was at the Siege of Nándorfehérvár (1456) in the entourage of King Ladislaus V (the Posthumous) of Hungary - wrote one of the first song-poems in reaction to the Fall of Constantinople in 1453. Entitled Von den Türken und dem adel sagt dis, these verses, translated here into English for the first time, have previously been neglected in scholarship. Beheim's perspective is particularly important, documenting as it does an emotional reaction to a defeat that spawned invective-filled rhetoric, crusading propaganda, castigation of the Christian nobility for a failure to come together, and an interpretation of the Turks under Mehmed II as a scourge of God. Beheim here, and in his subsequent body of anti-Turkish works, including his detailed depiction of the Crusade of Varna (1443-1445), contributes to the shaping of a late mediaeval and early modern negative Türkenbild.

Key words: Michel Beheim, Holy Roman Empire, Mehmed II, Ottoman Turks, Fall of Constantinople, 1453, crusading songs, propaganda, European nobility.

\section{Introduction}

Michel Beheim (1416?-1479?), a peripatetic poet, musical composer and performer, brought forth over 450 works representing a summa of mediaeval themes and poetic forms. ${ }^{1}$ He enjoyed patronage from the highest nobility of his day - most prominently Emperor Frederick III of Habsburg and King Ladislaus V (the Posthumous) of

\footnotetext{
${ }^{1}$ See the general treatments in McDonald (1981) and Niemeyer (2001). Useful, too, is the essay by Thum (1989) which focuses on the role of Beheim as one of the most important early Publizisten, commentators on politics and current affairs.
} 
Hungary $^{2}$ - and was active in wide reaches of Europe. Beheim was also a scribe and editor of his own work which he carefully conserved. The general categories of his oeuvre are religious songs, moral and ethical poetry, political and historical writing (including chronicles), autobiographical verse, love songs, fables, and songs on the nature and status of the singer's art. Subcategories are dynastic and urban history, anti-Jewish polemic, allegories of the world as a woman, vernacular homiletics, travel literature, the Deadly Sins, autobiography, biblical paraphrase, Marian song, the history of the University of Vienna, as well as topical verses on the outrages of the contemporary ruler, Vlad III Dracula, Prince of Wallachia. All of these topics and genres Beheim set to verse and song. He created twelve Töne (melodies and metres), forming song-cycles on heretics and saints, while promoting the cause of his current literary sponsor. Beheim also enjoyed urban patronage, having been employed by city governments (Augsburg, Nördlingen). Holding fast to an outmoded form of musical composition and vocal performance, Beheim cherished monophonic vocal music, writing scathingly against instrumental music. He retired, or was forced into retirement, when his final royal patron, Fredrick I, Count Palatine, welcomed to the court in Heidelberg performers proficient in the increasingly popular art of polyphonic music.

To the long list of song-types that Michel Beheim composed belong his diatribes against the Ottoman Turks, the genre that researchers label Türkenlieder. ${ }^{3} \mathrm{He}$ crafted almost a dozen of these, thus making him one of the era's fiercest literary opponents of the Turks in the arts. Puzzlingly, his anti-Turkish songs are absent from almost all anthologies, and no recent scholarship treats these in depth. This neglect is all the more baffling, since Beheim was actively involved in actions against the Turks. While in the retinue of Ladislaus he was at the Siege of Nándorfehérvár (1456), and reports about the campaign at length in a song-poem. He grants the most attention to the atrocities of the Turks, the heroics of the Franciscan provincial Giovanni da Capistrano, and the murder of Ulrich II, Count of Celje (No. 328). ${ }^{4}$ Further, as far as we know, Beheim composed a song-poem calling for a Turkish crusade for the Imperial Diet in Nuremberg (1466) (No. 101). ${ }^{5}$ Beheim's Turcica, to borrow the critical term employed by Carl Göllner, are useful for their autobiographical and historical references. ${ }^{6}$ One of these concerns the Crusade of Varna (1443-1445), the struggles of

\footnotetext{
${ }^{2}$ Király (2003, p. 42) notes that in 1455 Beheim is documented as Kunig Lasslaws Sprecher.

${ }^{3}$ Özyurt (1972) is most closely identified with this concept. Note that he does not include Michel Beheim in his volume.

${ }^{4}$ All song-poems are listed according to the edition of Gille-Spriewald (1968-1972). Concerning No. 328, see Müller (1974, pp. 252-253). Here Beheim refers to Belgrade as Kriechischen Weissenburg (cited in the title), that is, "Greek/Byzantine white fort/town", thus preserving its etymology. On the 1456 campaign, consult Fodor (2008).

${ }^{5}$ See Müller (1974, p. 266); and Gille (1910, pp. 139-144). On the German imperial assemblies dealing with Turkish crusades, see Helmrath (2004).

${ }^{6}$ Göllner (Vol. 3, p. 40) cites a brief passage from our song-poem, No. 446, concerning the recalcitrance of the princes to answer the papal call to crusades against the Turks. He borrows the stanza from Gille (1910).
} 
King Władysław III of Hungary and Poland, and János Hunyadi against Sultan Murad II. It contains a description of defeat of the Christian troops at the Battle of Varna (1444) and of the death of Władysław (No. 104). ${ }^{7}$ This paper considers Beheim's initial anti-Turkish song-poem, No. 446, written in the aftershock of the Fall of Constantinople in May 1453, Von den Türken und dem adel sagt dis (hereafter Von den Türken) (No. 446; Gille-Spriewald Vol. 3, pp. 290-292). ${ }^{8}$ A polemical work of 88 verses in the vernacular, it is a lament and call to action against Sultan Mehmet II the Conqueror (1432-1481) and his army. Because our song-poem arose in 1453, soon after the news had reached the German cultural area, it has historical significance. ${ }^{9}$ But more than this, Beheim's verses offer a window on the emotional reaction of Europeans who were shocked, fearful, and angry. In the same year, another German poet, Balthasar Mandelreiß, was commissioned by the Habsburg imperial court to compose an anti-Turkish poem, the notorious Türkenschrei. ${ }^{10}$ Both Beheim and Mandelreiß lament the loss of the city, calumniate the Turks and their ruler, Mehmet II, and urge the German nobility to unite in order to retake Constantinople. In spite of the fact that Von den Türken was one of the earliest poems in Europe - and perhaps the first in Germany - to comment on contemporaneous events in Constantinople, it largely has escaped scholarly notice. ${ }^{11}$ No discrete treatment of it exists in the critical literature. This is striking in the light of the flood of recent research concerning the image of the Turks and the response of European poets and statesmen in the arts to Turkish military conquest. It is our aim to remedy in small measure the neglect of Beheim's songpoem. It is to be hoped that his carmen will take its place alongside other, betterknown exemplars of crusading propaganda, for instance, Gaspare Tribraco's Carmen de apparatu contra Turcum (1464), mentioned by Göllner (Vol. 3, p. 36).

Here follows the first translation of Von den Türken into English.

${ }^{7}$ Composed between 1461 and 1466, this song-poem has recently been translated by Imber (2006, pp. 167-180). Beheim received most of his information on Varna from an eye-witness. See Engel (1994, p. 245), and Lukasiewicz (2012, p. 4). Still valuable are the investigations by Bleyer (1902) which treat the life and works of Michel Beheim against the backdrop of Hungarian history. See, especially, part IV, pp. 215-232. On Beheim and Varna, see, also, Srodecki (2015, p. 223).

${ }^{8}$ On reactions to the Fall of Constantinople, see Thumser (1997).

${ }^{9}$ On the reactions of observers contemporary to Michel Beheim, see Fleming (2003, p. 69) on the Hellenistic chronicler Chalconcondylas and Brandmüller (1995) on Pope Nicholas V.

${ }^{10}$ Text in Özyurt (1972, pp. 147-151). See also Geldner (1983) and Buchmann (1983, p. 17). Mandelreiß refers to kaiser Fridrich near the end of his poem as the point of orientation for the gathering army to do battle with the Turks (Stanza 31, p. 151).

${ }^{11}$ See brief references to No. 446 in Meuthen (1983, p. 7); Irmscher (1987, pp. 297-298); and Ackermann (2009, p. 195). 


\section{Von den Türken und dem adel sagt dis: Translation, Music, Genre, Sponsorship ${ }^{12}$}

Here I reveal to you / the greatest misery. / An M, four Cs, an L, three Is / are fourteen and a half centuries / and in the third year therefrom / after the birth of Jesus Christ, / the time the Greek crown perished. / This massacre / caused by an emperor / 10) from Turkey, as was told to me. / The evil heathen tyrant, dreadful Turk, / slayer of Christians, / laid waste to Constantinople. / Many Christians died therein, / thrice a hundred thousand people. / Many men and women, / all those over seven years, / he had them put to death. / A miserable slaughter and misery. / 20) You lords of the Roman Empire, / pope, emperor, king you're called, / and the lords and princes all, / you must feel shame at all the blood that has been spilled! / Damn your disgrace: / your rank allows you to / command so many people and lands, / yet let so many faithful folks / be murderously slain! / Their blood is on your hands! / 30) Had you done your duty / they would be still alive. / They'd supplicated every realm / that's subject to the Roman crown / before they were expelled. / They called on every nobleman. / No help was to be had. / You, oh lords and nobles, / if you have no desire / to battle Turks and infidels / it may be that you'll lose authority / 40) and fail to use your powers, / which Emperor Charlemagne in war / had gained for you with knightly valour. / Once they had had might and sway, / the Christian noblemen, / because they strove for knightliness / and manly bravery, / and when they heard there was in Christian lands / one who blemished Christian faith, / 50) they all rode off at once to fight / in the cause of Christianity, / because they all were unified and on one side. / In that way they won / great honour for themselves. / Now things have flip-flopped for the worse, / the Christians only quarrel. / And in these times one hears / nothing but war and strife, / murder, plunder and arson, / 60) the same in every land, / and those who call themselves Christian / in Hungary, Castile, without a doubt: / Poland, Bohemia, France, / Aragon, Apulia, England, too, / Portuguese, Scots, Swedes, and Danes. / The eagle now desires / to change to something new. / It's living in a foreign mode. / 70) It's turned into a scavenger. / It cooks up foreign ways. / It only flies above the towns / and feeds on hens and roosters. / Once it lived in noble style / and flew above the fields, / and in the woods it fed itself / on wild and woodland birds. / Since the Christian noblemen themselves / do harm and damage to each other, / 80) and each one's striving aims at this: / how one can drive the other out, / it's no wonder God will let our plans collapse / and stands apart from us / because of our misdeeds, / for Christian faith limps on a crutch. / Merciful God, you should bring / it back to its full power. / Grant us your help, it's what we need. ${ }^{13}$

${ }^{12}$ Title: This Tells about the Turks and the Nobility. The following (as yet unpublished) translation of No. 446 is courtesy of Dr. James Ogier, with the consultation of William C. McDonald. I here thank Justin Mueller (University of Virginia), Dr. Thomas Leek, Dr. Rebekah Slodounik, and James Rathjen for suggestions on the manuscript.

${ }^{13}$ There follows the original text to No. 446, Gille-Spriewald (1971, Vol. 3 / 1, pp. $290-$ 292): Ich tun euch hie / grass jamer affenpare. / ain m, vir ce, ain ell, drew iii / ist funff zehend halb hundert jare / und in dem driten zware / nach der gepurt Jhesu Kristi, / als dy kriechisch kran ist 
Von den Türken, like all of Beheim's vast oeuvre, welcomed two modes of reception, the reading mode and the listening mode. He explained this in another songpoem thusly: "One can read (the present text) as a rhymed book or can sing it as a song. He who wants to sing it should proceed with the following notes" (No. 453, title). ${ }^{14}$ Recognising that some might prefer to encounter his rhymed song texts as private reading material, that is as lectio and not as musical offerings in a public setting, he allows the individual audience member to decide which mode or presentation is appropriate. At court, Beheim performed his works to music in a communal setting. The melody of Von den Türken he named the Lange Weise (Long Tune), and he employed it for almost 30 song-poems, spanning biblical paraphrases, veneration of the Virgin, the Final Judgement, and the joys of heaven (Kühn 1907, pp. 119-121). Our song on the Turks is the only one on this topic within the musical grouping. It is embedded in a religious and moral-ethical context because of its theme: the loss of a Christian city inspires the poet's ruminations over a Turkish victory, the sinful conduct of Christian nobles, as well as over God's ultimate design. That Beheim prized Von den Türken is indicated by its appearance in three of his manuscripts (Heidelberg Cpg 312, 303v-304r; München Cgm 291, 391v-392v; Heidelberg Cpg 334, 434rv). Twice it is recorded in his own hand (Brunner-Wachinger 1986, p. 197).

Applying taxonomic categories, one sees that Von den Türken is difficult to label. Anti-Turkish songs of the 15 th century traditionally are divided into three main

verdarben. / Das selbig mort, / peschach von ainem keiser / 10) auss der Turkei, han ich gehort. / der haidenisch wütrich und freiser / und der kristen ver weiser / Cunstantinopel hat zerstort. / vil kristen sein dar inn gestarben, / Zu drei maln hundert tausent gar. / vil volkes, man und weibe, / waz da waz uber siben jar, / das liess er tun von leibe. / daz ist ein mort und jomer jemerleich. / 20) ir fursten in römischem reich, / babst, kaiser, küng mit namen, / und die fursten und hern alsamen, / dez blut vergiessens mussend ir euch ummer schamen! / pfei euch der schand, / daz ir in eurem stand / vermugend so gross leut und land / und lassent so vil kristen gut / so mördigleichen tamen! / ir seit schuldig an irem plut! / 30) Het ir getan, / sie weren wal peliben. / wann sy under der romschen kron / in alle reich haben geschriben, / e sie wurden vertriben. / all fursten sy da rufften an, / der hilff sy nit geniessen machten. / Ir furstn und hern, / welt ir euch nit gen disen / türken und ungetaufften wern, / 40) so welt ir eür macht gern verlisen / und den gewalt verkisen, / den euch mit riterlichen ern / kaiser Karolus hot er vachten. / Hie vor heten sie maht und krafft, / die kristenlichen fürsten, / wann sie wurben nach riterschafft / und manlichen getursten, / wann wu sie horten in der kristenhait, / das man dem glaben stifftet lait, / 50) da hin woren sie reiten, / umb kristen glăben willen streiten, / wann sy worn all in ainikait auff ainer seiten. / mit solchem sie / grass er erstriten hie. / nun hat es sich verkert mit mie / die kristen leben in zwitrecht. / wann man in disen zeiten / härt nichcz wann krieg und anevecht, / Mort, răb und prant / 60) in allen landen gleiche, / und die dann kristen sein genant / in Ungarn, Kastili sunder weiche: / Poln, Beham, Franken reiche, / Arragunn, Apüln, Engelant, / Schaten, Portigal, Sweden, Tennen. / Der adaler / wil sich verkern und newen. / in fremder art sa lebet er. / 70) er ist worden zu ainem wewen. / ain fremd art wil er breuwen. / er fleugt nun ob den darffern her / und nert sich der hanen und hennen. / Hie vor lebt er nach edler art / und flag ab dem gevilde, / und in der wiltnis er sich nart / von dem gefügel wilde. / seit die kristenlich fursten selber nun / ain ander laid und schaden tun / 80) und all nach solchem ringen, / wie ainr den andern mug ver tringen, / so ist nit wunder, ab uns got lest misselingen / und ab gestet / umb unser missetet, / wann kristen glab auff stelczen get. / den saltu, parmhercziger got, / wider zu krufften pringen. / tail uns dein hilff, daz ist uns not.

${ }^{14}$ Daz man es lesen mag als ain gereimptes puch oder singen als ain lied, and wer es singen well, der heb es in disen noten hie dishalb an. 
groupings: historical songs, religious songs, and so-called "newspaper songs", namely those songs reporting on the latest events in the world (Buchmann 1983, pp. 1819). ${ }^{15}$ Von den Türken fits none of these exactly. Instead, Beheim expands the register of known types by blending four literary forms into a hybrid whose unifying element is the tonal structure of the Lange Weise. The first of these modes is the threnody. He sings a lamentatio, a funeral dirge for the loss of life and the loss of the city itself to the Turks. ${ }^{16}$ Second, to counsel the Christian princes, Beheim draws on the familiar genre of the Speculum principum, the mirror of princes that offers models of behaviour for the ideal ruler to follow. The model that Beheim promotes has much in common with that of his contemporary, Francesco Filelfo, who advises the princes that proper statecraft requires a crusade against the Ottoman Turks (Meserve 2010). ${ }^{17}$ Third, he borrows from the crusading song, the Kreuzlied, a traditional genre very well-represented in the German Middle Ages. Walther von der Vogelweide (fl. 1200) offers exemplars of these, which convey, in the words of Hilda Swinburne, "general propaganda for the Crusades" as a holy war (Swinburne 1961, p. 351). That holy war for Beheim is military conflict with the Turks, the implication being that the timid nobles whom he castigates have no stomach to recover Constantinople, that is to say, to "battle Turks" (gen disen/türken ...wern; v. 38-39). Finally, and in conjunction with crusading propaganda, Beheim shapes Von den Türken into the song-type that Bertrand M. Buchmann has called an Aufruf: an invocation, a call, or direct summons to a military expedition.

The polemical Aufruf is, Buchmann informs us, semi-official, meaning that a patron, or political faction, stands behind it and that the singer is a spokesperson for them (Buchmann 1983, p. 36). In 1453 and for part of 1454 Michel Beheim was in the service of Duke Albrecht III of Bavaria-Munich. ${ }^{18}$ It is possible, of course, that Von den Türken arose on Beheim's own initiative, out of a well of feeling. Whatever the circumstances of composition, this song-poem is extremely ambitious, intended not for a single sponsor, but for the whole of Christendom - including the Papal court. ${ }^{19}$ In his verses he sketches the geographic reaches of the Christian world, in the West the British Isles and Spain, and in the East Poland and Hungary. Within the entire Christian realm, he scolds, those charged with guiding and directing affairs had failed Constantinople because of fraternal squabbles. Beheim lays the blame for defeat at the hands of the nobles collectively, the adel of the title, naming the pope, the emperor, kings, princes, and all those in authority. Internal strife, he argues, must be

\footnotetext{
${ }^{15}$ Die geistlichen Gesänge, die historischen Gesänge, die Zeitungslieder.

${ }^{16}$ In this context one is reminded of the motet of early 1454, also on the Fall of Constantinople, composed by Guillaume DuFay, Lamentio sanctae matris ecclesiae Constantinopolitanae.

${ }^{17}$ Filelfo promoted his crusading ideology through letters sent to Christian princes.

${ }^{18}$ On Michel Beheim's history of sponsorship, see Schanze (1983, pp. 183-190).

${ }^{19}$ Beheim's reference to the pope (babst; 446:21) as one of the deficient rulers (ir fursten [sic] in römischem reich, v. 20), may be rhetorical, of course. However, if he is indeed levelling a contemporary critique at the sitting pope, then he is alluding to Nicholas V (1447-1455). Regarding Pope Nicholas V and the Fall of Constantinople, see Brandmüller (1995).
} 
put aside forthwith in order to meet the external threat posed by the Turks. ${ }^{20}$ What Michel Beheim articulates is an elementary principle of political science: promotion of in-group solidarity in the face of out-group hostility.

\section{Poetic Organisation and Rhetorical Strategy}

The ruling theme of Von den Türken is the disunity within Christendom. The chief manifestation of this disunity is the contemporary Fall of Constantinople, to which Beheim devotes a lament. This expression of sorrow occupies the first fourth of his song-poem. Assuming the role of historian, the singer cites the year of defeat, the perpetrator, and the casualties. But his is tendentious history, making no pretense to objectivity. Beheim nowhere refers to Mehmed II by name, for example, instead hurling insult after insult, calling the otherwise unnamed keiser [sic] a heathen, despot, and killer of civilians. Besides slander, Beheim's history writing on Constantinople relies on exaggeration and charges of atrocities, the most egregious of which is to claim that 300,000 perished in the city. Slander and hyperbole prove here to be a tactic of persuasion, rhetorical tools that Beheim uses both to promote unity in Christendom and to rouse the nobles to action.

The next section of Von den Türken assigns blame and inculcates shame. The singer curses the nobles for inaction, placing the blood of innocents in Constantinople on their hands. The nobility has squandered its power by permitting citizens of the city to be slaughtered. Christian nobles were deaf to pleas for help; they ignored members of their religious faith behind city walls. Observe that each reference to events in Constantinople is transmitted through negative, inflammatory speech, the rhetoric of public humiliation for inactivity.

At the centre of Von den Türken lies a threat. Those nobles who are too cowardly to battle Turks and the unbaptised will forfeit their authority (v. 39). This threat is combined with further shaming, through a reference to past glories of the knightly class. Charlemagne and his champions were brave and moral, while today's nobles are cowardly and sinful. Earlier Germans possessed knightly virtues, whereas the current nobles are murderous arsonists. The world is now upside down, Beheim laments, because those in authority not only fail to exercise valour and courtliness, they quarrel, thus promoting disunity.

The last part of the song-poem comprises a direct call to Christendom to quit sinning (cowardice, internal strife, exercise of the Deadly Sins) and to embrace solidarity. A further shaming device is the metaphor of the eagle. This once proud symbol of the Empire has been replaced by a low-flying rapacious bird whose prey is domestic fowl, not wild birds (read: Turks). Now God enters Von den Türken. The

${ }^{20}$ One must be struck by the similarity in argument when Jensen $(1985$, p. 451$)$ speaks of the efforts of Aeneas Sylvius Piccolomini, Pope Pius II (1458-1464), to deal with "squabbling princes" in order to lead them to a new crusade. "Few of the princes could be moved into action", Jensen observes, "even when the Turks raided the coasts of Italy itself". See Rowe (1961) and Helmrath (2000). 
song-poem concludes with a divine entreaty, having two purposes. The first is to propose that God permitted the Fall of Constantinople because of moral failings in Christian rulers. The second is to appeal to heaven to bring the Christian realm again to ascendancy. That ascendancy brings with it the recovery of the holy city of Constantinople.

In order to incite the Christian nobles to action, Beheim chooses to demonise Mehmed II and his followers. He does so, first, by referring to the Fall of Constantinople as wanton slaughter (mort; v. 8). This sets the tone for the invective to come, which is directed at Mehmed II. It is he who was responsible for the recent massacre and misery (v. 19). Four negative terms in a single rhymed couplet are directed at Mehmed II: heathen, tyrant, slayer, and expeller of Christians (haidenisch [sic] wütrich und freiser / und der kristen ver weiser, v. 11-12). The intent is to turn every member of his audience against the Turkish ruler by portraying the victor over Constantinople as a fully evil man, a ruthless villain who murdered women and children. Of the invective directed at the sultan, a key concept is wütrich (v. 11), a favorite expression of opprobrium in Beheim's greater work. Wüt(e)rich, the equivalent of Latin tyrannus, is best rendered as "despot", "oppressor", or "tyrant" - and thus communicates political slander at its core. ${ }^{21} \mathrm{He}$ applies wütrich (in variant spellings) to Dracula (No. 99: Title and v. 1, 271, and 609), ${ }^{22}$ Antiochus (No. 164: 80), and again to Mehmed II in a later song-poem. ${ }^{23}$ In calling Mehmed II a ruler who fails to exercise power justly, Beheim aims for more than mere insult. He is questioning the very foundation of his foe's claims to command. This means that Constantinople was conquered by a man who, while in a position of authority, had ruled despotically. A European consensus had already formed around the qualities of good governance in the 12th century (see Galbraith 1945 and Weiler 2005). Secular power articulated itself in a commonly accepted set of duties and behavioural norms. By branding Mehmed II a tyrant, Beheim signals that the sultan had breached all the European standards of conduct practiced by good and just rulers. This autocrat, as Beheim wants his audience to understand, belongs in the company of Dracula and Nero.

Twice the word mort appears in the brief passage on Mehmed II in Von den Türken (v. 8 and 19). Mort, it needs to be stressed, is not simply the one-to-one equivalent of "murder", that is to say, of modern Mord. A mortal sin, mort, is an emotionally and theologically laden term with wide valence in Beheim's era, extending to

${ }^{21}$ See Grimm (1960, p. 2524) as a corrective to most translations of wüterich/wüetreich in our lexica and scholarship. Most render it as Wüterich, wütender, tobender Mensch (English: "violent madman"), when Latin tyrannus is the best equivalent, that is, a ruler who exercises power arbitrarily, unjustly, and oppressively. The synonyms would be "despot", "autocrat" - even "dictator". Nero is the classic example. For Beheim, Dracula, Antiochus, and Mehmed II make up a trio of despots deserving the pejorative title wüterich.

${ }^{22}$ Note that Turks were very much on Beheim's mind when he composed his Dracula songpoem (circa 1462). Beheim makes the interactions of Vlad III with the Turks a warning example. The lesson he hopes to convey is that those partnering with the Turks deserve punishment, even death. See McDonald (2014).

${ }^{23}$ Beheim uses the epithet again in the song-poem on the Siege of Nándorfehérvár (1456), mentioned above, No. 328: v. 62, 296, and 472. 
"evil deed", “treachery", “carnage”, and "slaughter”. Slaughter captures best Beheim's sense of mort when he alludes to the sultan's behaviour in Constantinople. For him, Mehmed II is a heathen who cut down innocents, a monster visiting a civilian population with unspeakable, barbaric atrocities. The insults that Beheim hurls at Mehmed II are familiar to later investigators of anti-Turkish poems in Europe, a genre thriving deep into the 17 th century (see Buchmann 1983). ${ }^{24}$ Demonising remarks regarding the so-called Turkish peril arose from the phenomenon Türkenfurcht, a sense of horror and panic at Turkish expansion and from fears that Turkish invasion was imminent (Schulze 1995). In this atmosphere of dread there arose an arsenal of anti-Turkish clichés and stereotypes. These have been exhaustively investigated and catalogued: Eastern horde, barbarians, cruelty, mass murderers, arch-enemy of Christendom and more. ${ }^{25}$ The Turk manifested "other-ness", a sensual creature of distorted physiognomy that embodied menace to Western society (see Schwoebel 1967, Barbarics 2001, Höfert 2003 and Jezernik 2010). Many in fact believed that Mehmed II was Antichrist himself, sent to punish Christians for their sins (Emmerson 1981, pp. 67ff.).

Nedret Kuran-Burçoğlu makes the crucial point that the Fall of Constantinople was the watershed moment for representations of the Turk in Germany (Kuran - Burçoğlu 2009, pp. 15ff.). After 1453 a decidedly negative image prevails, as we have documented in Beheim's Von den Türken. It is important to establish that when Michel Beheim directed his de-humanising remarks at Mehmed II and the Ottoman Turks, anti-Turkish tropes were by no means fixed. His verses permit an aperture into the gestation stage of vituperative rhetoric that flowered in the 16th century. It can therefore be argued that Beheim helped to shape the phenomenon that Bozidar Jezernik has called "Imagining the Turk" (Jezernik 2010). ${ }^{26}$ One of Beheim's contributions to the reservoir of negative images - and an indication of the escalating negative rhetoric - is his characterisation, around 1457, of Mehmed II as a "nasty dog" (argen hunde; $328,68)$.

\section{Conclusion}

Von den Türken, composed as a song and a poem in the shock of the moment after the Fall of Constantinople, is crusading literature that pleaded for European unity and military action against the Turks. It failed on both counts. The nobles came no closer to unified purpose and crusade appeals were ignored. As James Hankins (1995, p. 144) reminds us, during the rule of Mehmed II, "no great pan-European crusade was launched between the accession of the Conqueror in 1451 and his death in 1481". The ambivalent position of Frederick III on a crusade against the Ottoman Empire is

\footnotetext{
${ }^{24}$ On the history of the Türkenbild, see Kleinlogel (1989).

${ }^{25}$ On the negative stereotypes and invective regarding the Turks and Islam, see Smith (1966) and Hankins (1995, p. 119).

${ }^{26}$ Cf. also Soykut (2003) and Tafilowski (2015).
} 
well known. ${ }^{27}$ At times the emperor promoted a crusade, as in 1453 , when he sent Bernhard II, Margrave of Baden-Baden, to the European princes in order to gather funds for battle against the Turks. He also called for the Diet of Regensburg in 1454 to consider a crusade. But at most other times he showed little enthusiasm for military action, having resisted the calls for a crusade from four succeeding Popes (Nicholas V, Pius II, Callixtus III, and Paul II). It is thus difficult for us to interpret Frederick's decision to extend patronage, from 1459-1465, to Michel Beheim, a fervent promoter of crusading ideology, a fierce opponent of Mehmed II, and a veteran of military action in Belgrade (1456), while in the company of Ladislaus. What we know is that, during his time at Frederick's court, Beheim composed two song-poems promoting anti-Turkish sentiments. The first we have already mentioned, his lengthy treatment of the Varna campaign (No. 104). There Beheim relates this history of Christian defeat at the hands of Sultan Murad II, not least in order to make the Fall of Constantinople understandable. The second, Von dem übel stand under dem adel (No. 98 ), composed in 1460, begins with a lament to the nobility on the horrors of the year, among which are Hungarian losses to the Turks. He scolds the princes, claiming that they should feel shame because "the Turk in this year has driven about 60,000 souls from Hungary". ${ }^{28}$ He goes on to list other failings of European rulers. It soon becomes apparent that, in respect to theme and ideology, this song-poem is the pendant to Von den Türken. These two song-poems even share the trio of sins that plague the rulers of Europe at mid-century: slaughter, looting, and arson (No. 98: 39). Disunity is again the theme. A unified European nobility, claims Beheim, is the prerequisite to taking up arms against the Turks.

By repeating the argument of Von den Türken in Von dem übel stand under dem adel, a full seven years after the Fall of Constantinople, Michel Beheim makes it clear that no progress has been made against the Turks. He likely performed Von dem übel stand under dem adel before the emperor - but no crusade was forthcoming. Returning to Von den Türken, we conclude with the necessary reminder that these verses arose during the fraught period when authors were struggling to comprehend that a bulwark of Christian culture had fallen. In the words of Frank Richard Trombley (2010, Title), those writers contemporary with the Fall of Constantinople were forced to communicate "the experience of defeat". Beheim's Von den Türken is crisis poetry - and song. It not only bridges artistic media, it mixes genres, privileging crusading propaganda, even as it laments the defeat of the city. Beheim's didactic verses hold much to interest the researcher. They are starkly contemporary, a very early reaction to events as perceived within the highest social strata of Europe. They show Christendom in confusion, a faith community that wants to blame someone for the military defeat. The most logical choice is Mehmed II, of course, but fascinatingly,

${ }^{27}$ On Frederick III and a proposed crusade against the Turks, see Rowe (1961). Göllner (Vol. 3, pp. 44-53) is especially good regarding the emperor's procrastination about crusading. See, for example, Göllner's reference to the author Michael Apostolis and his direct (failed) appeal to Frederick (op. cit., p. 52).

${ }^{28}$ Als dann der Turk in disem jar / pei sechczig tausent menschen zwar / auss Ungern hat getriben; No. 98: 61-63). 
Beheim fails to place the responsibility for the conquest of Constantinople on his shoulders. Instead, the singer castigates the entire spectrum of Christian rulers, from the pope to the lesser lords, on account of their quarrels and their failure to confront the Turks on the battlefield. He accuses the Christian nobles of slaughter, plunder, and arson (mort, răb und prant; v. 59), evil deeds that place the populace in danger. ${ }^{29}$ The first of this triad, mort, must attract our attention, for it is the very term that Beheim had employed in an earlier passage in Von den Türken. There mort described the evil deeds of Mehmed II (v. 8 and 19). Thus joined through the shared practices of murder and carnage, Christian rulers and the sultan now share a standard of morality - at least on the level of rhetoric. Given the heavy burden of Christian transgression, it is therefore not a surprise, Beheim concludes, that God has punished Christendom for its misdeeds. He interprets that punishment as the Fall of Constantinople, which is God's vengeance for sinful discord and dissention in the ruling classes. It would then follow that the Turks are agents of divine will, bringing both warning and chastisement to Christians.

These very sentiments, the Turks as a scourge of God, appear some decades later in Germany in Türkenbüchlein, printed pamphlets and tracts on the Turkish threat to Christendom that appeared between 1522 and $1543 .^{30}$ Their authors - like Beheim - saw the Ottoman Turks, in the words of John W. Bohnstedt (1968, Preface), as "aggressive representatives of the alien and hostile world of Islam, the traditional antagonist of Christendom". Bohnstedt (Ibid, pp. 25-26), without mentioning Beheim, reveals that the Türkenbüchlein advance the two propositions that we have traced here: "all estates in Christendom were shamefully disregarding their divinely imposed duties to society" and "the Turkish peril was a visitation inflicted by God upon a sinful Christendom". The fact that both arguments were repeated decades after the composition of Von den Türken shows both that Beheim's song-poem was pioneering in its sentiments, and that his sort of rhetoric had become customary.

\section{References}

Ackermann, Christiane (2009): Dimensionen der Medialität. Die Osmanen im Rosenplütschen 'Turken Vasnachtspil' sowie in den Dramen des Hans Sachs und Jakob Ayrer. In: Ridder, K. (ed.): Fastnachtsspiele. Weltliches Schauspiel in literarischen und kulturellen Kontexten. Tübingen, pp. 189-220.

Asutay-Effenberger, Neslihan - Rehm, Ulrich (2009): Sultan Mehmet II. Eroberer KonstantinopelsPatron der Künste. Köln-Weimar-Wien.

${ }^{29}$ Beheim once again ascribes this triad of crimes (mort, raub und prant) to quarrelling Christian nobles, this time in a song-poem under Ladislaus, dated 1455/56 (No. 237: v. 119). Instead of attacking each other and living in sin, Beheim claims, the nobles should be battling the Turks. 16th century.

${ }^{30}$ See Göllner (Vols 2 and 3: 1968 and 1978). He edits the European Türkendrucke of the 
Barbarics, Zsuzsa (2001): ,Türck ist mein Nahm in allen Landen...' Kunst, Propaganda, und die Wandlung des Türkenbildes im Heiligen Römischen Reich Deutscher Nation. $A O H$ Vol. 54, pp. 257-317.

Blanks, D. R. - Frasetto, M. (1999): Western Views of Islam in Medieval and Early Modern Europe. Perceptions of the Other. New York.

Bleyer, Jakab (1902): Beheim Mihály élete és művei a magyar történelem szempontjából [Michael Beheim and his works from the viewpoint of Hungarian history]. Századok Vol. 36, pp. $21-46,131-138,215-232,347-369,444-463,528-564$.

Bohnstedt, John W. (1968): The Infidel Scourge of God. The Turkish Menace as Seen by German Pamphleteers of the Reformation Era. Transactions of the American Philosophical Society Vol. 58, pp. 1-58.

Brandmüller, Walter (1995): Die Reaktion Nikolaus' V, auf den Fall von Konstantinopel. Römische Quartalschrift für christliche Altertumskunde und Kirchengeschichte Vol. 90, pp. 1-22.

Brunner, Horst - Wachinger, Burghart (1986): Repertorium der Sangsprüche und Meisterlieder des 12. bis 18. Jahrhunderts. Band 3. Tübingen.

Buchmann, Bertrand Michael (1983): Türkenlieder zu den Türkenkriegen und besonders zur zweiten Wiener Türkenbelagerung. Wien.

Emmerson, Richard Kenneth (1981): Antichrist in the Middle Ages. A Study of Medieval Apocalypticism, Art, and Literature. Seattle.

Engel, Pál (1994): János Hunyadi and the 'Peace of Szeged' (1444). AOH Vol. 47, pp. 241-257.

Fleming, K. E. (2003): Constantinople. From Christianity to Islam. The Classical World Vol.97, pp. 69-78.

Fodor, Pál (2008): The Ottoman Empire, Byzantium and Western Christianity. The Implications of the Siege of Belgrade, 1456. AOH Vol. 61, pp. 43-51.

Galbraith, V.H. (1945): Good Kings and Bad Kings in Medieval English History. History Vol. 30, pp. 119-132.

Geldner, Ferdinand (1975): Der Türkenkalender. ,Ein manung der christenheit wider die durcken: ' Mainz 1454. Das älteste erhaltene gedruckte Buch: Faksimile und Kommentarband. Wiesbaden.

Geldner, Ferdinand (1983): Bemerkungen zum Text des ,Türkenschreis‘ von Balthasar Mandelreiß, des ,Türkenkalenders‘ (1454) und der ,Ermanung wider die Türken` von Niclas Wolgemut. Gutenberg Jahrbuch Vol. 58, pp. 166-171.

Gille, Hans (1910): Die historischen und politischen Gedichte Michel Beheims. Berlin.

Gille, Hans - Spriewald, Ingeborg (1968-1972): Die Gedichte des Michel Beheim. 3 vols. Berlin.

Göllner, Carl (1961-1978): Turcica. 3 vols. Bucharest.

Grimm (1960): Deutsches Wörterbuch von Jacob Grimm und Wilhelm Grimm. Hrsg. von der Deutschen Akademie der Wissenschaften zu Berlin. Vierzehnten Bandes, II. Abteilung, Sechzehnte Lieferung: Wuscheln-Ysop. Leipzig, pp. 2524-2525.

Hankins, James (1995): Renaissance Crusaders. Humanist Crusade Literature in the Age of Mehmed II. Dumbarton Oaks Papers Vol. 49, pp. 111-207.

Helmrath, Johannes (2000): Pius II. und die Türken. In: Guthmüller, B. - Kühlmann, W. (eds): Europa und die Türken in der Renaissance. Tübingen, pp. 79-138.

Helmrath, Johannes (2004): The German Reichstage and the Crusade. In: Housley, Norman (ed.): Crusading in the Fifteenth Century. Message and Impact. Basingstoke-New York.

Höfert, Almut (2003): Den Feind beschreiben: ,Türkengefahr ' und europäisches Wissen über das Osmanische Reich 1450-1600. Frankfurt am Main-New York.

Housley, Norman (ed.) (2016): The Crusade in the Fifteenth Century. Competing Cultures. New York-London. 
Imber, Colin (2006): The Crusade of Varna, 1443-45. Aldershot-Burlington.

Irmscher, Johannes (1987): Das Ende Neuroms in der Sicht der deutschen Zeitgenossen. Illinois Classical Studies Vol. 12, pp. 293-304.

Jensen, De Lamar (1985): The Ottoman Turks in Sixteenth-Century French Diplomacy. The Sixteenth-Century Journal Vol. 16, pp. 451-470.

Jezernik, Bozidar (2010): Imagining the 'Turk'. Newcastle upon Tyne.

Király, Péter (2003): Die Musik am ungarischen Königshof in der ersten Hälfte des 15. Jahrhunderts von der Zeit Sigismunds von Luxemburg bis zu Mathias Corvinus. Studia Musicologica Academiae Scientiarum Hungaricae Vol. 44, pp. 29-45.

Kleinlogel, Cornelia (1989): Exotik-Erotik. Zur Geschichte des Türkenbildes in der deutschen Literatur der frühen Neuzeit (1453-1800). Frankfurt am Main.

Kühn, Alfred (1907): Rhythmik und Melodik Michel Beheims. Bonn.

Kuran-Burçoğlu, Nedret (2009): Reflections on the Image of the Turk in Europe. Istanbul.

Lukasiewicz, Krystyna (2012): Deceptive Practices in Fifteenth-Century Europe. The Case of Wladyslaw III Jagiellon (Varnensis). The Polish Review Vol. 57, pp. 3-20.

McDonald, William C. (1981): Whose Bread I Eat. The Song-Poetry of Michel Beheim. Göppingen.

McDonald, William C. (2001): Michel Beheim. In: Jeep, J. (ed.): Medieval Germany. An Encyclopedia. New York-London, pp. 46-47.

McDonald, William C. (2014): Michel Beheim's Song-Poem on Dracula. Some Notes and a Translation. In: Jefferis, S. (ed.): Festschrift Ulrich Müller. Vol. I. Göppingen, pp. 187-230.

Meserve, Margaret (2010): Nestor Denied. Francesco Filelfo's Advice to Princes on the Crusade against the Turks. Osiris Vol. 25, pp. 47-65.

Meuthen, Erich (1983): Der Fall von Konstantinopel und der lateinische Westen. Historische Zeitschrift Vol. 237, pp. 1-35.

Müller, Ulrich (1974): Untersuchungen zur politischen Lyrik des deutschen Mittelalters. Göppingen.

Naumann, Thomas (2010): Feindbild Islam. Historische und theologische Gründe einer europäischen Angst. In: Islamfeindlichkeit. Wenn die Grenzen der Kritik verschwimmen, 2nd edition. Tübingen, pp. 20-36.

Niemeyer, Friederike (2001): Ich, Michel Pehn. Zum Kunst- und Rollenverständnis des meisterlichen Berufsdichters Michael Beheim. Frankfurt am Main.

Özyurt, Senol (1972): Die Türkenlieder und Türkenbild in der deutschen Volksüberlieferung vom 16. bis zum 20. Jahrhundert. München.

Rowe, John Gordon (1961): The Tragedy of Aeneas Sylvius Piccolomini (Pope Pius II). An Interpretation. Church History Vol. 30, pp. 288-313.

Schanze, Frieder (1983): Meisterliche Liedkunst zwischen Heinrich von Mügeln und Hans Sachs. Band I: Untersuchungen. München-Zürich.

Schanze, Frieder (1985): Balthasar Mandelreiß. In: Ruh, K. et al. (eds): Die deutsche Literatur des Mittelalters. Verfasserlexicon. Band 5, pp. 1200-1201.

Schulze, Winfried (1995): Türkenfurcht im 16. Jahrhundert. In: Haarmann, M. (ed.): Der Islam. Ein Lesebuch. München, pp. 256-259.

Schwoebel, Robert (1967): The Shadow of the Crescent. The Renaissance Image of the Turk (1453-1517). Nieuwkoop.

Simon, Eckehard (1988): The 'Türkenkalender' (1454) Attributed to Gutenberg and the Strasbourg Lunation Tracts. Cambridge, Mass.

Smith, Leslie F. (1966): Pope Pius II's Use of Turkish Atrocities. The Southwestern Social Science Quarterly Vol. 46, pp. 407-415. 
Soykut, Mustafa (2003): Historical Image of the Turk in Europe. 15th Century to the Present: Political and Civilizational Aspects. Istanbul.

Srodecki, Paul (2015): Antemurale Christianitatis. Zur Genese der Bollwerksrhetorik im östlichen Mitteleuropa an der Schwelle vom Mittelalter zur Frühen Neuzeit. Husum.

Swinburne, Hilda (1961): Walther von der Vogelweide and the Crusades. The Modern Language Review Vol. 56, pp. 349-353.

Tafilowski, Piotr (2015): Anti-Turkish Literature in 15th-16th-Century Europe. Tarih Incelemeleri Dergisi Vol. 30, pp. 231-280.

Thum, B. (1989): Die Publizistik Michel Beheims im Spannungsfeld des spätmittelalterlichen Populismus. In: Krüger, R. - Kühnel, J.-Kuolt, J. (eds): Ist Zwîvel Herzen Nâchgebûr. Günther Schweikle zum 60. Geburtstag. Stuttgart, pp. 203-223.

Thumser, Matthias (1997): Türkenfrage und öffentliche Meinung. Zeitgenössische Zeugnisse nach dem Fall von Konstantinopel (1453). In: Erkens, F-R. (ed.): Europa und die osmanische Expansion im ausgehenden Mittelalter. Berlin, pp. 59-78.

Trombley, Frank Richard (2010): The Fall of Constantinople in 1453 and Late Medieval Greek Culture. The Experience of Defeat. Groniek Historisch Tijdschrift Vol. 184, pp. 267-284.

Weiler, Björn (2005): William of Malmesbury on Kingship. History Vol. 90, pp. 3-22. 